\title{
Fænomenologi og antropocentrisme
}

\author{
NICOLAI KREJBERG KNUDSEN
}

SUMMARY: This article poses the question: Is phenomenology anthropocentric? In the first half, I show that both Husserl's and Heidegger's philosophy take their point departure in the relation between the human being and the world, but that they both also argue that their respective analysis transcends the horizon of anthropology by inquiring into meaning or being as such. I then distinguish between ontological, epistemological, and ethical anthropocentrism and argue that these forms of anthropocentrism do not necessarily imply each other. In the next half, I focus on Heidegger's analysis of the animal. I argue that Heidegger's philosophy is ontologically anthropocentric but neither epistemologically nor ethically anthropocentric. In opposition to posthumanism, my thesis is that the particular kind of ontological anthropocentrism that characterise Heidegger and phenomenology is a presupposition rather than an obstacle for the capacity for understanding and caring for other creatures. I call this position anthropoeccentrism.

RESUME: Denne artikel stiller spørgsmålet: Er fænomenologien antropocentrisk? I den første halvdel viser jeg, at både Husserls og Heideggers filosofi ganske vist tager udgangspunkt i menneskets forhold til verden, men at de begge mener, at deres respektive analyser overskrider antropologiens spørgehorisont ved at spørge om mening eller væren som sådan. Dernæst skelner jeg mellem ontologisk, epistemologisk, og etisk antropocentrisme og argumenterer for, at disse former for antropocentrisme ikke nødvendigvis følger af hinanden. I den næste halvdel fokuserer jeg på Heideggers analyse af dyret. Jeg argumenterer for, at Heideggers filosofi er ontologisk antropocentrisk, men hverken epistemologisk eller etisk antropocentrisk. I modsætning til posthumanismen er min tese, at den særlige form for ontologisk antropocentrisme, der kendetegner Heidegger og fænomenologien, er en forudsætning snarere end en forhindring for evnen til at kunne forstå og drage omsorg for andre væsner. Denne position kalder jeg for antropoexcentrisme.

KEYWORDS: Anthropocentrism; phenomenology; Husserl; Heidegger; posthumanism 
Inden for visse dele af filosofien har klima- og biodiversitetskrisen foranlediget en selvransagelse, hvor man spørger sig selv om filosofiens begreb om 'mennesket' i virkeligheden står i vejen for et nyt og mere harmonisk natursyn og -forhold. Er filosofiens begreb om 'mennesket', som Foucault påstod i Ordene og tingene, blot en historisk forekomst, der 'vil blive visket bort, som et ansigt af sand ved havets bred' (Foucault 2006, 364)? Denne selvransagelse kommer mest radikalt til udtryk i posthumanismen og den spekulative realisme, der argumenterer for, at Vestens filosofiske tradition er udpræget antropocentrisk, idet alle dens facetter - både den teoretiske og den praktiske del - beror på den problematiske forestilling om mennesket som animal rationale og imago dei, som hævet over og adskilt fra den øvrige natur.

Denne 'post-antropocentriske vending' (cf. Braidotti 2013; Ferrando 2016) finder sted i kritisk dialog med det 20. århundredes kontinentalfilosofi. På den ene side bygger posthumanismen og den spekulative realisme på fænomenologi, strukturalisme og dekonstruktion; men på den anden side påstås det ofte, at disse tidligere teoriudviklinger er antropocentriske. Dette fører naturligvis til både receptionshistoriske og systematiske spørgsmål. Er dette en fair kritik? Og i hvor høj grad forhindrer filosofiens påståede forankring i mennesket os i at erkende og drage omsorg for andre livsvæsner?

I denne artikel vil jeg tage udgangspunkt i fænomenologien og spørge hvorvidt fænomenologien er antropocentrisk. Det vil dog hurtigt vise sig, at dette tilsyneladende så simple spørgsmål kompliceres af en række forskellige forhold. For det første viser et par historiske nedslag hurtigt, at fænomenologien, i hvert fald i sin egen selvforståelse, langt fra lader sig reducere til en navleskuende undersøgelse af mennesket og dets erfaringshorisont. For det andet er det slet ikke klart, hvad der egentlig menes med termen 'antropocentrisk'. da de typiske måder at bruge denne term på ukritisk sammenblander ontologiske, epistemologiske og etiske problemstillinger. Først når vi har afklaret disse spørgsmål giver det mening at vurdere hvorvidt fænomenologien er antropocentrisk, og hvor problematisk en sådan antropocentrisme eventuelt måtte være.

Artiklen er inddelt $i$ to hovedafsnit. I afsnit 1 (Mennesket $i$ centrum) skitserer jeg problemfeltet ved at redegøre for fænomenologiens forhold til antropologien med særligt fokus på Husserl og Heidegger (1.1) og ved at skelne mellem ontologisk, epistemologisk og normativ antropocentrisme (1.2). I afsnit 2 (Mennesket som excentrisk) diskuterer jeg hvorvidt Heideggers fænomenologi er antropocentrisk ved at kigge nærmere på hans analyse af dyret i forelæsningsrækken Die Grundbegriffe der Metaphysik fra 1929-30 (2.1). Dernæst rekonstruerer jeg det etiske potentiale i Heideggers fænomenologiske tilgang til andre livsvæsner ved at argumentere for, at den præ-reflektive åbenhed over for og forståelse af andre livsvæsner, der præsenteres i denne forelæsningsrække, er en forudsætning for at kunne drage omsorg for andre livsvæsner. Jeg argumenterer dermed for, at Heideggers fænomenologi kan læses som en form for antropoexcentrisme (2.2).

Artiklens konklusion står i modsætning til den pointe, der kendetegner den postantropocentriske vending. I sidste ende bliver det nemlig klart, at fænomenologiens 
ontologiske forankring i menneskets væren er en mulighedsbetingelse snarere end en forhindring for at kultivere forstående og ansvarlige forhold til andre livsvæsner.

\section{Mennesket i centrum}

Før vi kan diskutere, hvorvidt fænomenologien skal forkastes som antropocentrisk, er det nødvendigt at afklare, hvordan fænomenologien selv forholder sig til 'mennesket' som begreb, idé og problemfelt. Dette vil jeg gøre i form af en række historiske nedslag. Dernæst vil jeg diskutere, hvad der præcist ligger i begrebet 'antropocentrisme' med henvisning til posthumanisme og spekulativ realisme.

\section{Fænomenologiens frygt for mennesket}

Fænomenologien udgør en form for radikalisering af Kants kopernikanske vending $\mathrm{i}$ den forstand, at filosofiens primære opgave bliver at afdække, hvordan forskellige objekter fremtræder som meningsfulde i kraft af bevidsthedens konstitutive aktivitet. Studiet af menneskets erfaringsverden bliver i fænomenologien førstefilosofi. Det er nærliggende at mene, at filosofiens horisont dermed bliver identisk med horisonten for den menneskelige erfaring, og at fænomenologien derfor er et antropocentrisk foretagende fra start til slut.

Fænomenologiens forhold til mennesket er dog mere komplekst end som så. Forholdet er kendetegnet ved en grundlæggende spænding, da man på den ene side ganske rigtigt insisterer på, at filosofien skal løsne og gøre os opmærksomme de intentionelle tråde, der, som Merleau-Ponty siger, binder mennesket til verden [les fils intentionnels qui nous relient au monde] (Merleau-Ponty 1945, viii). På den anden side, mener fænomenologerne dog ikke, at fænomenologien kan reduceres til en filosofisk antropologi, for hvis fænomenologien blot er en (selv)udfoldelse af menneskedyrets ontologi, kan fænomenologien umuligt grundlægge de øvrige videnskaber eller besvare spørgsmålet om værens mening, hvilket vil sige, at så kan fænomenologien ikke være førstefilosofi.

Lad os kigge nærmere på denne spænding ved først at fokusere på, hvordan fænomenologien er flettet sammen med en særlig forestilling om menneskets væren, for bagefter at undersøge, hvordan fænomenologiens spørgehorisont, i hvert fald i sin egen selvforståelse, også kommer bag om menneskets væren i en afdækning af verden som sådan.

Det er afgørende, at fænomenologien, inspireret af Kant, begrunder selve muligheden for filosofi i den særlige form for væren, der kendetegner mennesket. Husserl overtager således i grove træk Kants forståelse af mennesket som dels et transcendentalt, dels et empirisk væsen, og insisterer på, at denne dobbelthed udgør selve mulighedsbetingelsen for den fænomenologiske undersøgelse. I epoché er det således vigtigt, at vi ikke blot sætter parentes om vores naturlige tro på verdens eksistens, men også om vores egne interesser, præferencer og historie som individuelle mennesker. Vi skal, med andre ord, adskille os fra os selv som empiriske væsner, når vi filosoferer, og 
dermed opnå en 'transcendental ensomhed' (Husserl 1987, 171). Dobbeltheden i menneskets væren, dels empirisk individ, dels transcendentalt ego, tillader os at undersøge verdenskonstitutionen.

Heidegger modsætter sig af forskellige grunde Husserls terminologi og metode; men den særegne dobbelthed, der muliggør filosofi som fænomenologi, forbliver den samme. Dasein (der måske, måske ikke, er sammenfaldende med det, vi kalder mennesket) er ontisk-ontologisk. I modsætning til Husserl (og Kant) mener Heidegger ikke, at vi klart kan skelne mellem de nødvendige (transcendentale) og de kontingente (empiriske) elementer af vores i-verden-væren. I stedet mener han, at filosofien udspringer af og skal lede tilbage ind i det faktiske liv. Pointen med analysen af omhuen [Sorge] er netop, at vi ikke skal abstrahere fra de praktiske, affektive og personlige dimensioner af menneskelivet, når vi skal beskrive verdensforholdet. Og dog er filosofi kun mulig, fordi Dasein udmærker sig ved, 'at det for dette værende i dets væren drejer sig om denne væren selv’ (Heidegger 2007, 31). Kendetegnende for Dasein er altså, at det har en værensforståelse, der som udgangspunkt måske nok er forvirret og vag, men som ikke desto mindre udgør det hermeneutiske kardinalpunkt for en 'udarbejdelse af mulighedsbetingelserne for enhver ontologisk undersøgelse' (s. 58). Dasein er altså det eneste værende, der kan lede til en fundamental- frem for en blot regionalontologi.

Væren og tid siger ikke meget om dyr; men det er underforstået, at denne måde at 'gå op i sin egen væren' på udgør både en antropologisk differens og mulighedsbetingelsen for filosofi som sådan. I en senere formulering, som jeg vender tilbage til nedenfor i "Antropocentrismen hos Heidegger", udpensler Heidegger den kontrast til dyrene, som kun lå implicit i den tidlige formulering, når han siger, at mennesket er verdensbyggende, dyret er verdensfattigt, og stenen er verdensløs (Heidegger 1983).

På linje med den filosofiske tradition tager fænomenologien altså afsæt i idéen om, at mennesket på en eller anden måde er exceptionelt. Menneskets væren adskiller sig på væsentlige punkter fra dyrenes væren, og hvordan vi end beskriver denne antropologiske differens, er det her vi skal finde selve filosofiens mulighedsbetingelse.

Spørgsmålet er så, hvorvidt dette i sidste ende ikke gør fænomenologien til en art antropologi, for man arbejder tydeligvis med en ontologi, der er modelleret over den antropologiske differens, og som om det ikke var nok, insisterer man af metodologiske årsager på, at filosofien hverken kan eller skal overskride analysen af vores (subjektets, bevidsthedens, Daseins) forhold til verden. Som Derrida skriver i 1968 som en kommentar til forholdet mellem fænomenologi og humanisme med henvisning til især Sartre, men også til Husserl og Heidegger:

\footnotetext{
Såfremt den beskriver den menneskelige virkeligheds strukturer, er fænomenologisk ontologi en filosofisk antropologi. Uanset hvilke afgørende forskelle til klassiske antropologi der ellers kendetegner denne hegelsk-husserliansk-heideggerske antropologi, er der ingen afbrydelse af den metafysiske lighed, der så naturligt forbinder filosofernes 'vi' til 'vi-mænd' [nous-hommes], til dét 'vi', der udgør hele menneskehedens horisont (Derrida 1972, 137).
}

Faren er med andre ord, at den fænomenologiske ontologi bliver en regionalontologi i form af en filosofisk antropologi - altså hverken mere eller mindre end et studie af 
menneskets særlige værensform. På trods af sine egne universelle ambitioner bliver den fænomenologiske analyse dermed snarere en analyse af menneskets forhold til verden end en analyse af menneskets forhold til verden.

Fænomenologien er pinligt bevidst om denne fare. Man kunne endda skrive fænomenologiens historie som en historie om fænomenologiens frygt for antropologien. En udtømmende historisk oversigt ville kræve adskille kapitler og dermed overskride denne artikels fokus; men et par historiske nedslag kan tjene til at illustrere, hvordan fænomenologiens forskellige brudflader i høj grad handler om at udvikle en filosofi, der måske nok tager afsæt i menneskets forhold til verden men som netop forsøger at bruge dette som springbræt til at belyse dét, der transcenderer en antropologisk spørgehorisont.

I 1931 holder Husserl et foredrag under titlen "Phänomenologie und Anthropologie," hvori han konstaterer, at samtidens tyske filosofi udviser en spirende interesse for filosofisk antropologi. Dette kommer klarest til udtryk i Diltheys livsfilosofi; men tendensen har, som Husserl konstaterer, også greb i den fænomenologiske bevægelse, hvor Scheler og Heidegger (der dog ikke nævnes ved navn) forsøger at gøre menneskets 'konkret-verdenslige eksistens' [konkret-weltlichen Daseins] til grundlaget for filosofien. I denne udvikling ser Husserl en grundlæggende modsætning til sin egen transcendentale fænomenologi (Husserl 1987, 164f), og foredraget har til formål at diskutere, hvorvidt en antropologisk fænomenologi overhovedet kan være filosofisk, eller om den snarere er symptom på en dybere metodisk og faglig forvirring.

Filosofien skal, ifølge Husserl, være en ny videnskab, der kan grundlægge alle de andre videnskaber (inklusive psykologi og antropologi) (s. 165). Det afgørende skridt, der skal hjælpe os med at indfri denne ambition, er den fænomenologiske reduktion, der, som nævnt ovenfor, beskrives som en transcendental ensomhed, hvori vi træder tilbage fra vores konkrete liv som empiriske væsner, eftersom vi ikke fra dette udgangspunkt kan stille spørgsmålstegn ved og dermed kritisk undersøge verden og dens forskellige værensområder:

\footnotetext{
Som ego er jeg for mig selv ikke mennesket i den eksisterende verden, men derimod det 'jeg,' der stiller spørgsmål til verden med henblik på al dens væren og dermed også al dens væren-sådan [Soseins], eller det 'jeg,' der gennemlever den universelle erfaring, men har sat parentes om dens værensgyldighed (Husserl 1987, 171).
}

Reduktionen er nødvendig, for at vi kan analysere verden som fænomen og ikke blot ukritisk antage dens eksistens eller værensgyldighed. I reduktionen fremtræder verden fortsat som den plejer; men den er 'sat i parentes', gjort til et blot fænomen, hvis grundlæggende strukturer således kan beskrives af det transcendentale ego.

Problemet er, at en filosofi, der tager udgangspunkt i den konkret-verdenslige eksistens, aldrig kan hæve sig langt nok over sine partikulære historiske og praktiske omstændigheder til at sige noget om verdensfænomenet som sådan. Dermed kan den filosofiske antropologi ikke indfri Husserls ambition om at grundlægge videnskaberne. Den kan højst gøre sig forhåbninger om at være en metode blandt andre, der kan benyttes inden for etnografien og psykologien. Husserl mener dermed, at den an- 
tropologiske fænomenologi end ikke kan redegøre for verdenskonstitutionen og derfor falder tilbage i den naivitet, som den moderne filosofi i Husserls optik har som sin primære opgave at overkomme (s. 179). Som han konkluderer i slutningen af foredraget:

Jeg kan ikke andet end at anse beslutningen for endegyldig og erklære, at alle filosofier, der kalder sig selv fænomenologiske uden overhovedet at være i stand til at nå den egentlige filosofiske dimension, er vildfarelser (ibid.).

For at opsummere kan vi sige, at fænomenologien som transcendentalfilosofi nødvendigvis tager udgangspunkt i mennesket som det eneste væsen, der kan foretage den fænomenologiske reduktion, men at Husserl samtidig (i kontrast til den filosofiske antropologi) insisterer på, at filosofien må hæve sig over menneskets partikulære indlejrethed i verden for at redegøre for de antagelser, som de øvrige videnskaber ukritisk bygger på. Filosofien skal altså tage udgangspunkt i mennesket, dog ikke som et faktisk og individuelt liv, men som det subjekt, der konstituerer verden og gør transcendental erkendelse mulig. Hvis vi starter med den 'konkrete-verdenslige eksistens' er vi nødsaget til at tage den verdenskonstitution for givet, som fænomenologien har som sin primære opgave at forklare.

Hvis vi nu vender os mod Heidegger, havde han i løbet af sine år som Husserls assistent allerede foregrebet deres uenighed og kritiseret sin læremester i såvel forelæsningsrækker som i dele af hovedværket Væren og tid, der udkom i 1927 i tidsskriftet Jahrbuch für Phänomenologie und phänomenologische Philosophie, redigeret af netop Husserl. Ironisk nok går en væsentlig del af Heideggers kritik på, at Husserls fænomenologi skulle udgøre en art filosofisk antropologi, hvilket ses tydeligt i §10 i Væren og tid, der har til formål at afgrænse Daseinsanalytikken fra biologi, psykologi og antropologi. Den af Heidegger fremførte kritik af biologien og psykologien minder på sin vis om Husserls allerede nævnte kritik af Diltheys livsfilosofi og psykologismen; men for Heidegger dækker termen 'antropologi' over den fænomenologiske 'personalisme', som han finder hos Husserl og Scheler. Ifølge Væren og tid er det således Husserl, der 'udviser tendenser i retning af en filosofisk antropologi' (Heidegger 2007, 67).

Scheler og Husserl roses for, at de - i modsætning til store dele af traditionen - har indset, at personen (dvs. menneskets væren) hverken kan eller bør betragtes som en ting eller som en substans, men derimod begribes som 'fuldføreren af intentionale akter, der er forbundet gennem enheden af en mening' (s. 68). Denne negative bestemmelse - at menneskets væren ikke kan begribes som en substans - mangler dog at blive fuldt op af en positiv ontologisk bestemmelse. Både Scheler og Husserl (særligt i Ideen II) forfalder, i Heideggers optik, til den klassiske forståelse af mennesket som en 'legemlig-sjælelig-åndelig enhed' (s. 69), hvilket vil sige, at de bygger deres fænomenologiske forståelse af menneskets væren på en klassisk græsk-kristen metafysik. ${ }^{1}$

1 I Ideen II ser vi, hvordan denne tredelte ontologi bliver afgørende for Husserls forståelse af forskellen på mennesker og dyr. Han medgiver, at både menneske og dyr har eller er kroppe [Leib] og ikke blot legemer [Körper]. Dette vil sige, at når vi betragter både dyr og mennesker, er der på den ene side givet en erfaring af et (deleligt) spatialt legeme; men på den anden side 
I en forelæsningsrække fra 1925 går Heidegger mere i dybden med denne kritik. Problemet med Husserls analyse er, kort sagt, at den anser mennesket for at være en blot ting i verden, der består af mange lag (Heidegger 1975, 173) - dels legemlig, dels psykisk og dels åndelig - men at den aldrig spørger yderligere ind til enheden af disse bestemmelser. Som Heidegger retorisk spørger sine studerende:

Er denne definition draget ud fra erfaringer, der sigter mod en primær erfaring af menneskets væren, eller kommer den ikke snarere fra erfaringen af mennesket som en forhåndenværende ting i verden - animal - der har fornuft - rationale - som en iboende egenskab? (s. 174).

Kritikken går på, at disse fænomenologiske udlægninger af mennesket, formentlig mod fænomenologernes vilje, kommer til at videreføre den klassiske definition af mennesket i stedet for at tage afsæt $\mathrm{i}$ en egentlig analyse af menneskets væren, som den fremtræder for os i erfaringen.

På dette punkt kan det undre, hvordan Heidegger, der jo netop er optaget af spørgsmålet om menneskets væren, kan kritisere Husserl for at bedrive antropologi. Heideggers argument er det følgende: En analyse af mennesket (som det værende for hvilket verden fremtræder) er udgangspunktet for fænomenologien, fordi denne analyse kan belyse verden som menneskets korrelat (eller verden som fænomen). Hvis dette er tilfældet, er en fejltagelse vedrørende menneskets væren på samme tid en fejltagelse vedrørende verden (eller vedrørende væren som sådan). Kun den rette analyse af mennesket, qua Dasein, kan åbne op for spørgsmålet om væren som sådan. Antropologiske fejltagelser fører altså til ontologiske fejltagelser (og omvendt).

Schelers og Husserls begreb om personen som en enhed af legeme, sjæl og ånd fremstiller altså indirekte verden som et korrelat bestående af distinkte meningslag, hvis nederste og mest fundamentale lag er det værende som ren legemlig objektivitet (Heidegger 1975, 173). Den græsk-kristne antropologi fører således til en traditionel og i sidste ende kartesiansk ontologi (s. 180). Heideggers alternativ viser derimod, at menneskets væren har en grundlæggende tidslig struktur, jævnfør omhuens struktur som kastet-udkastende. I kraft af den ovenfor skitserede korrelation mellem Dasein og verden bliver denne bestemmelse af menneskets væren også afgørende for spørgsmålet om værens mening og dermed også vores mulighed for at forholde os til andre værender, inklusiv andre livsvæsner.

Hvis man ville, kunne man fortsætte dette narrativ og undersøge, hvordan frygten for antropologien ligeledes nærer Heideggers kritik af andre samtidige tænkere som Helmuth Plessner og Jean-Paul Sartre, hvordan den påvirker hans til tider nidkære

er der også givet en erfaring af, at dette legeme er en krop, der er sæde for en (udelelig) bevidsthed (Husserl 1991, 33). På denne måde tilskriver bevidstheden mentale tilstande samt motor-intentionalitet til både menneske og dyr. Mennesket har dog - udover disse to meningslag - et tredje meningslag, nemlig ånd [Geist]. Set ud fra dette perspektiv (som Husserl kalder for den personalistiske attitude) ændrer kroppens mening sig fuldstændigt, og der opstår en grundlæggende forskel på dyrets krop og menneskets krop, fordi menneskets krop nu forstås på baggrund af en større, åndelig meningshorisont, der involverer sociale, kulturelle og historiske strukturer (cf. Ciocan 2019). 
forhold til sine egne studerende (såsom Karl Löwith og Hannah Arendt), og hvordan den senere bliver afgørende i den selvkritik, der markerer overgangen fra en 'tidlig' til en 'sen' Heidegger. ${ }^{2}$ Man kunne ligeledes udbygge fortællingen til også at omfatte dekonstruktionen, hvis forhold til og kritik af fænomenologien også næres af en frygt for antropologien, om end nu i form af en afstandtagen til logocentrisme og den dertilhørende humanisme. Dette bliver dog for omfattende, og disse to historiske nedslag må være tilstrækkelige til at påvise, at fænomenologien på den ene side beror på og består af en analyse af menneskets væren, men at den på den anden side konstant forsøger at differentiere sig fra antropologien, eftersom den som filosofi nærer ambitioner om en udsigelseskraft, der transcenderer den blotte analyse af mennesket som en type objekt blandt andre.

\section{Tre former for antropocentrisme}

Noget tyder på, at man har ramt et ømt punkt, når man anklager fænomenologien for at være antropocentrisk. Lad os dog kigge lidt nærmere på dette begreb, der i dag bliver brugt i flæng. Hvad indebærer det egentlig at være antropocentrisk?

Et forsøg på en definition finder vi hos den selverklærede posthumanist Rosi Braidotti. Posthumanisme består, ifølge hende, i en 'kritik af det humanistiske ideal om mennesket [Man] som den tilsyneladende universelle målestok for alle ting'. Posthumanisme er, per definition, en post-antropocentrisme, der 'kritiserer artshierarkier og menneskelig exceptionalisme' (Braidotti 2019, 2). Hvis vi går kritisk til værks, bliver det tydeligt, at Braidottis definition (som så mange andre) sammenblander en række forskellige former for antropocentrisme, der måske nok hænger sammen historisk, men som kan og bør adskilles analytisk.

For det første hentyder Braidotti med sin term 'menneskelig exceptionalisme' til det, vi kan kalde en ontologisk antropocentrisme. Den ontologiske antropocentrisme påstår kort sagt, at der er et klart ontologisk skel mellem mennesker og alle andre dyr, og at mennesket udgør en form for undtagelse i forhold til resten af naturens rige. Ontologisk antropocentrisme tager således afsæt i en klar antropologisk differens. Man er således antropocentrisk i denne ontologiske forstand, hvis man i overensstemmelse med den vestlige idéhistorie postulerer en ontologisk forskel mellem menneske (det livsvæsen, der har fornuft) og dyr (alle de andre, ikke-fornuftige livsvæsen). Det er netop denne ontologiske antagelse, der spøger i baggrunden, når vi taler om 'dyr' eller 'dyret' som en samlet (mod)kategori. ${ }^{3}$

2 For en yderligere diskussion af Heideggers forhold til den filosofiske antropologi og især hans forhold til Plessner, se Wentzer 2017.

3 Man kunne argumentere for, at den ontologiske antropocentrisme allerede funderes i filosofiens mytiske rod, nemlig det delfiske orakels 'kend dig selv' [gnothi seauthon]. Filosofien er den aktivitet, der udfolder selvets forhold til sig selv, og det filosoferende subjekt er det selvreflekterende subjekt. Hos Carl Linnaeus, der opfandt biologiens klassifikationssystem, finder vi denne tanke gengivet i værket i Systema Naturæ fra 1735, hvor mennesket måske nok indplaceres i 'naturens system' blandt de andre primater, men under homo sapiens' artskendetegn står der 
Den næste form for antropocentrisme er epistemologisk og indfanges i Protagoras' diktum: Mennesket er altings målestok. De stærkeste argumenter - eller måske snarere, den stærkeste modstand - mod epistemologisk antropocentrisme finder vi i den spekulative realisme. Her argumenterer man imod kongstanken (fra Kant og den postKantianske filosofi, inklusiv fænomenologien), at menneskets/subjektets transcendentale erkendelsesbetingelser former verden på en sådan måde, at vi altid kun har adgang til verden for os frem for verden $i$ sig selv (eller verden, som den fremtræder for andre væsner/ting). Quentin Meillassoux kalder dette for korrelationisme. ${ }^{4}$ Idéen i den spekulative realisme er, at vi ontologisk må tillade, at andre væsner også har korrelationer (dvs. har sine egne transcendentale, verdensformende erkendelsesbetingelser), og at vi epistemologisk må søge at komme hinsides vor egen korrelation og forstå verden, som den er i sig selv eller, i det mindste, som den er for ikke-menneskelige skabninger.

Med Timothy Mortons populærkulturelle terminologi har traditionen insisteret på, at kun mennesket har et verdensforhold, og nu handler det om at frisætte 'den antropocentriske copyright control' (Morton 2017, 10f), så alle væsner og ting kan siges at have et verdensforhold i form af et sæt af (quasi-)transcendentale erkendelsesbetingelser, der former verden i et arts- eller tingsspecifikt for os.

Udfordringen er selvfølgelig, at idéen om andre korrelationer ikke blot bør forblive et spekulativt postulat, og at vi derfor må have en metode, der tillader os at sprænge rammerne for vores egen korrelation. Vi må altså kunne give os seriøst svar på Thomas Nagels berømte spørgsmål: 'Hvordan er det at være en flagermus?' (Nagel 1974). Nagel mener, at vi højest kan tilnærme os en objektiv forståelse af flagermusens erkendeapparat; men kritikeren af den epistemologiske antropocentrisme må insistere på, at det er muligt for os at tilnærme os selve flagermusens subjektive erfaringsdimension - $\mathrm{i}$ Nagels termer, "[what] it is like to be that organism - [what] it is like for the organism" (s. 436).

Måske vi kan sige, at kritikken af den ontologiske antropocentrisme står over for en historisk-konceptuel udfordring (nemlig, hvordan tænker vi hinsides den metafysiske tradition og de grundbegreber, som den vestlige idéhistorie og videnskabsteori bygger på), og at kritikken af den epistemologiske antropocentrisme står over for en metodisk udfordring, fordi den på den ene side insisterer på, at korrelationer definerer, hvordan

blot en enkelt formaning: 'Kend dig selv!' [Nosce te ipsum!]. Menneskets evne til at begribe sig selv er dets særlige kendetegn og netop heri ligger forskellen til alle de andre livsvæsner. Dette er i øvrigt et eksempel på det, som Giorgio Agamben kalder den 'antropologiske maskine': Mennesket udgør en undtagelse fra naturen i kraft af, at mennesket bestandigt ekskluderer sig selv fra dyrenes rige og dermed adskiller sig fra det dyriske i sig selv (Agamben 2004, 26).

4 'Med "korrelation" mener vi ideen, ifølge hvilken vi altid kun har adgang til korrelationen mellem tænkning og væren, og aldrig disse to elementer adskilt fra hinanden. Vi vil fremover kalde enhver tankestrømning, der insisterer på korrelationens uoverskridelige karakter som defineret på denne måde, for korrelationisme' (Meillassoux 2014, 5). 
verden er for os mennesker, og på den anden side insisterer på, at det må være muligt for os at komme hinsides denne korrelation og forstå andre væsners korrelationer.

Der er forskellige bud på, hvordan dette kan lade sig gøre, som kun kan behandles ganske overfladisk her. I den ontologiske antropologi muliggøres det radikale perspektivskifte af shamanisme; i Ian Bogosts alien phenomenology får vi adgang til andre korrelationer ved at bruge metaforer og analogier såsom "the bat operates like a submarine" og "the redness hues like fire" (Bogost 2012, 64). ${ }^{5}$ Det mest radikale (og nok også mest fjollede) bud på, hvordan vi overkommer den epistemologiske antropocentrisme, finder vi hos Charles Foster, der i bogen i Mit liv som dyr beretter om sine forsøg på simpelthen at leve som grævling, odder, hjort, ræv og fugl ved på bedste vis at efterligne deres respektive bevægelsesmønstre, næringskilder, habitat, osv. ${ }^{6}$

Den tredje og sidste variant af antropocentrismen er den normative eller etiske antropocentrisme, der implicit eller eksplicit rangordner arterne efter værdi på en sådan måde, at menneskeliv altid er mere værd end andre former for liv (og måske endda den eneste form for liv, der har en værdi i sig selv). Denne antagelse udfordres af miljøog dyreetikken såvel som af den posthumane etik.

Braidotti hentyder til den normative antropocentrisme i sin definition, når hun skriver, at posthumanismen 'kritiserer artshierarkier'. Andetsteds uddyber hun, at humanismens idé om mennesket på ingen måde er uskyldigt, men indeholder et normalitetsideal, ifølge hvilken mennesket primært er hvidt, mandligt, heteroseksuelt, og at dette normalitetsideal på samme tid fungerer som et moralsk ideal og som et magtredskab, der ekskluderer andre former for liv:

Alle disse 'andre' gengives som forværring, som patologiserede og udstødte af normaliteten, på siden af anomali, afvigelse, monstrøsitet og bestialitet. Denne proces er i sig selv antropocentrisk, kønsbaseret og racialiseret, idet den opretholder æstetiske og moralske

5 Ifølge Bogost er problemet med Nagels afvisning af intermodale analogier som adgang til subjektive erfaringer, at Nagels eksempel ("Red is like the sound of a trumpet" (Nagel 1974, 449)) er dårligt, slet og ret. Men hos Bogost bliver det aldrig klart, hvordan vi overhovedet kan skelne mellem gode og dårlige analogier. Kernen i problemet er jo, at selve målestokken for en sådan vurdering er utilgængelig per definition.

6 Det skal bemærkes, at Foster til tider er bevidst om det absurde i sit foretagende. Når han skal forklare forholdet mellem menneskets sansning og de respektive dyrs sansning, svinger han mellem det, som Nagel ville kalde et objektivt standpunkt, der beskriver dyrets sanseapparat i termer, der i princippet er tilgængelige for alle væsner ( $\mathrm{fx}$ hvilke frekvenser grævlingen kan høre, hvordan trykbølgerne via trommehinden omsættes til elektriske impulser, der ender i hjernebarken, osv.), og en blank erkendelse af, at han simpelthen ikke ved, what it is like at være det respektive dyr. Han skriver fx: 'Grævlingen hører, når fasanerne letter fra markens udkant, generatorens dunkelyde oppe ved huset, skovsangerens mjavlyde, fårets angst, når det sidder fast $i$ trådhegnet og en fjern rumlen af torden. Deres ører registrerer alle disse ting, og der vil kort efter pågå elektrisk aktivitet i de auditive dele af deres hjernebark. Hvad "hører" den enkelte grævling som en konsekvens af de skiftende trykbølger, der rammer dens trommehinde, hvilket er hvad vi kalder lyde? Jeg har faktisk ingen anelse' (Foster 2018, 57). - Det ironiske i hele foretagendet er, naturligvis, at denne 'objektive beskrivelse', der antages at være det tætteste vi kommer på at overskride vores egen korrelation, ikke bringer os tættere på dyrets subjektive erfaringshorisont, men derimod, som Nagel også bemærker, bringer os længere væk fra den (Nagel 1974, 445).

Fænomenologi og antropocentrisme 49 
idealer baseret på hvid, maskulin, heteroseksuel europæisk civilisation (Braidotti 2013, $68)$.

Som modsvar til denne normative antropocentrisme udvikler hun så efterfølgende en posthuman etik, der tager udgangspunkt i livet som sådan (græsk: zoe) frem for menneskets liv (græsk: bios). Dette kalder hun en 'zoe-centreret egalitarisme':

Zoe-centreret egalitarisme er, for mig, kernen af den post-antropocentriske vending: den er en materialistisk, sekulær, jordnær og usentimental respons til den opportunistiske tværartslige markedsgørelse af Livet, der udgør logikken af den fremskredne kapitalisme (s. 60).

\section{Mennesket som excentrisk}

Spørgsmålet er nu: Hvor slemt står det til med fænomenologiens antropocentrisme? Af plads hensyn vil jeg udelukkende fokusere på Heidegger; men man kunne ligeledes have stillet dette spørgsmål til fx Husserl, Merleau-Ponty, Løgstrup eller Beauvoir. Først vil jeg kigge på, hvad Heidegger rent faktisk skriver i forhold til ontologisk og epistemologisk antropocentrisme, hvorefter jeg vil videreudvikle hans position i forhold til spørgsmålet om normativ antropocentrisme.

\section{Antropocentrismen hos Heidegger}

Man skelner sjældent mellem de tre forskellige former for antropocentrisme, og historisk set har de da også fungeret som en samlet pakke, hvor normativ antropocentrisme begrundes i epistemologisk og/eller ontologisk antropocentrisme. Man kan således argumentere for, at dyrene ikke fortjener moralsk respekt (normativ antropocentrisme), fordi de i modsætning til mennesket ikke besidder fornuft (ontologisk antropocentrisme), eller at dyrene har mindre moralsk værdi (normativ antropocentrisme), fordi vi ikke kan leve os ind i deres lidelse på samme måde, som vi kan med andre mennesker (epistemologisk antropocentrisme).

Selvom disse former for antropocentrisme historisk set har fulgtes ad og til dels stadig gør det, er det et åbent spørgsmål, hvorvidt de hører sammen med nødvendighed. Jeg vil her argumentere for, at de tre former for antropocentrisme kan og bør adskilles analytisk. Først skal vi dog kort overveje, om og på hvilken måde Heideggers specifikke variant af fænomenologien er antropocentrisk.

Heideggers ontologiske antropocentrisme finder vi, som allerede antydet, udtrykt i den trefoldige tese, at mennesket er verdensbyggende, dyret verdensfattigt, og stenen verdensløs (Heidegger 1983). For at forstå denne distinktion kan vi kigge nærmere på et af Heideggers eksempler: Billen. Det er klart, at billen har en relation til objekterne i verden. Objekterne fremtræder, ifølge Heidegger, for billen som 'bille-ting': Græsstrået er fx en sti for billen, som kan hjælpe den med at nå sin bille-næring (s. 292). På dette punkt minder billen om mennesket, som vi kender det fra Væren og tid, eftersom også mennesket afdækker sine omgivelser som instrumenter på baggrund af en allerede forudsat meningsfuldhed. Græsset er for billen en sti, mens det for mennesket er noget, der skal bindes i et neg og fodres til kvæget. 
Den ontologiske forskel består ifølge Heidegger i, at dyret ikke har adgang til det værende som værende (s. 292). Sagt med andre ord består dyrets verdensfattighed $i$, at det har en anden og mangelfuld forståelse af væren. Dette fører direkte til den epistemologiske antropocentrisme, såfremt den ontologiske tese indebærer, at dyret tilsyneladende har en anden form for adgang til det værende end mennesket. Hvilken adgang har dyret? Og hvilken adgang har vi til dyrets adgang?

Som det også er tilfældet for mennesket, fremtræder det værende for dyret på baggrund af dets indlejrethed i et netværk af relationer (mellem, fx næring, bytte, fjender, mager, osv.). Forskellen er, at dyret er bundet til sin omverden på en sådan måde, at dets omgivelser udelukkende kan fremtræde på baggrund af dyrets biologisk og fysiologisk fastsatte instinkter og evner. Med en term inspireret af Jakob von Uexkülls biologi siger Heidegger, at dyrets omverden udgør en 'disinhibitionsring' [Enthemmungsring], hvor dyret instinktivt reagerer på hvad end der er inden for denne ring. Med andre ord er dyret fanget i en omverden, hvis mening udtømmes af dets instinkter. At dyret ikke kan forstå det værende som værende betyder dermed at dyret ikke forstår det værende som noget, der har en eksistens uafhængigt af den organisme (dyret selv) for hvilket det fremtræder. Det følger heraf, at dyret heller ikke forstår det værende som noget, der kan afdækkes anderledes af andre typer af organismer. Verdensfattigheden består altså $i$, at dyret i mødet med sin omverden står over for en ren affekt, der ikke har nogen væren ud over dyrets eget perspektiv (s. 369).

Ironisk nok vender Heideggers analyse af dyret altså den epistemologiske antropocentrisme på hovedet. Det er således ikke længere mennesket, der antages at lade sin korrelation udtømme verden, men dyret, der har adgang til det værende som ren tilsynekomst. Det er dyret, der ifølge Heidegger, er fanget i en stærk korrelationisme, hvor det værende fremtræder som et blot korrelat for dets egen livsførelse. Det afgørende spørgsmål er så, om mennesket kan forstå dyrets korrelation? Eller formuleret med Heidegger: 'Kan vi overhovedet forsætte os i dyret [in das Tier versetzen]?' (s. 295).

På dette punkt er Heidegger væsentlig mere optimistisk på fænomenologiens vegne end posthumanisterne. For at forstå Heideggers bekræftende svar på dette spørgsmål må vi dog først klargøre, hvad der ligger i termen 'forsættelse' [Versetzung]. På hverdagstysk betyder det 'forflyttelse' (som mellem to arbejdspladser eller positioner) eller 'forrykkelse' (som en genstand, der flyttes lidt); men Heidegger spiller også på ligheden med termen for oversættelse [übersetzung]. Når jeg oversætter termen med 'forsættelse' og 'at forsætte', er det altså i den sjældent brugte betydning at forflytte eller forskyde.

Heidegger stiller altså et grundlæggende spørgsmål om socialkognition mellem arter: Hvad sker der med min forståelse af verden, når dyret træder ind i den? Heidegger skynder sig at distancere sig fra gængse måder at besvare dette spørgsmål, når han påpeger, at forsættelse hverken involverer en operation, hvor vi kognitivt lader, som om vi er i dyrets sted (s. 297), eller en form for indføling eller indlevelse, hvor vi emotionelt skaffer os adgang til en fremmed bevidsthed, der antages at have været lukket af for os (s. 298). Forsættelse er altså ikke en kognitiv eller emotionel perspektivovertagelse. Pointen er $i k k e$, at jeg skal sætte mig i dyret sted og se verden gennem dets øjne 
(s. 296). Jeg mener derimod, at Heidegger forsøger at beskrive en mere grundlæggende form for socialkognition. Termen 'forsættelse' henviser først og fremmest til den forskydning af vores forståelseshorisont, der finder sted, så snart det andet livsvæsen fremtræder for os. Denne forskydning er ikke en intellektuel eller en følelsesmæssig bedrift (som det, for eksempel, er, hvis man prøver at forestille sig, hvordan det er at være i flagermusens sted). Forsættelsen er ikke en bedrift, fordi det er noget, der sker umiddelbart - uafhængigt af, om vi vil det eller ej. Mennesket forstår verden som et handlings- og mulighedsrum, og at forsætte sig i dyret betyder, at dette handlings- og mulighedsrum forrykkes en smule. Der sker af den simple grund, at der i denne verden nu fremtræder et andet livsvæsen, der opererer inden for sit eget mulighedsfelt. Så snart vi forstår dette, har verden (i betydningen mulighedsrum) forrykket sig en lille smule, uden at vi overhovedet behøvede at skænke det en tanke, og uden at vi først oplevede det andet livsvæsen som noget mystisk og aflukket, der først skulle underkastes en eksplicit fortolkning. Heideggers opgave er dermed at vise, hvordan vort eget perspektiv på verden altid allerede er responsivt i forhold til de andre livsvæsner, som vi møder.

Heidegger beskriver mødet med det andet væsen som en form for 'gåen-med' [Mitgehen]. Han mener hermed, at vi ikke blot forstår omgivelser i forhold til os selv, og hvad vi selv er, men at vi ligeledes forstår omgivelserne på baggrund af 'hvad' og 'hvordan' de andre væsner, som vi møder, er (s. 296). Vi følges, så at sige, ad i vores forhold til verden. Jeg 'går med' et andet væsen, når jeg forstår dette væsen på baggrund af dets interesser og generelle engagement i de omgivelser, som vi har til fælles. Med en anden terminologi, delvist lånt fra Donald Davidson (1982), kan vi sige, at forsættelse udgør en præ-reflektiv triangulering, hvor jeg forstår både mig selv, mine omgivelser og det fremmede væsen på baggrund af de (handlings)muligheder, der udgøres af vores fælles engagement i verden.

Pointen er, at denne præ-reflektive triangulering åbner mig for andre væsners perspektiv, uden at jeg dermed er tvunget til at lade, som om jeg har forladt mit eget perspektiv på verden, som det ville være tilfældet, hvis forståelsen af dyret primært foregik via en kognitiv simulation. Forsættelsen i forhold til både dyr og mennesker er ikke en kognitiv opgave, som jeg kan foretage mig eller ej, men udgør en grundlæggende responsivitet over for andre væsner, som jeg ikke kan vælge til eller fra, og som jeg ikke kan værne mig imod. Mødet med det fremmede væsen udgør i sig selv en forsættelse eller præ-reflektiv triangulering, såfremt dette møder indebærer bare et mindstemål af forståelse. Som Heidegger konstaterer om vores forhold til dyret:

I spørgsmålet 'Kan vi forsætte os i dyret?' forudsætter vi ubestrideligt, at en 'gåen-med' [Mitgehen] i forhold til dyret, en følgen-med [Mitgang] i dyrets tilgang og omgang med dets verden, er mulig og ikke fuldstændig meningsløs. Der kan slet ikke stilles spørgsmålstegn ved, at dyret som sådan bærer en sfære af forsættelighed [Sphäre der Versetzbarkeit] med sig. Det eneste spørgsmål, der er tilbage, er den faktiske succes af vores forsætten-os-i disse bestemte sfærer. Det eneste spørgsmål, der er tilbage, går på [om vi besidder] de faktisk nødvendige målestokke for en virkeliggørelse af en sådan forsætten-sig-i og disses faktiske grænse (Heidegger 1983, 299). 
Det er slet ikke meningsfuldt at betvivle vores evne til at sætte os over i dyret - for selvfølgelig har dyret en sfære eller horisont, der giver os noget at forstå - om end vores faktiske evne til at forstå forskellige dyr naturligvis har visse begrænsninger. Når Heidegger således siger, at vi grundlæggende [grundsätzlich] altid er åbne over for dyret, kommer det endda til at lyde som om, at vores samværen [Mitsein] med dyret har samme transcendentale status, som den præ-reflektive triangulering, der finder sted mellem mennesker (s. 304), eftersom vi tilsyneladende ikke kan undsige os denne samværen. ${ }^{7}$ Denne analyse, der har det eksplicitte formål at kaste yderligere lys over verdensproblemet ved hjælp af kontrasten til dyret (s. 263f), kan altså også læses som en udbygning og udvidelse af den sociale holisme, der præsenteres i Mitsein-kapitlet i Væren og tid. Hvor Væren og tid præsenterer det andet menneske [Mitdasein] som forankringspunktet for en fri projektion af muligheder (i kraft af omhuens uundgåelige henvisning til et selv), får vi i denne forelæsningsrække en fortolkning af dyret som en bevægelse, der finder sted i det særlige mulighedsrum, der er dets disinhibitionsring. For at udtrykke pointen med en aristotelisk terminologi, der ligger Heidegger ganske nær, udgør dyret en kinesis, der skal forstås på baggrund af sin egen telos. ${ }^{8}$

Set fra dette synspunkt bliver forskellen mellem menneske og dyr, at mennesket står i et frit forhold til det mulighedsrum, der udgør verden, hvorimod dyret er bundet til sine instinkters muligheder. Mennesket er dermed verdensbyggende i den forstand, at det ontologisk særegne ved mennesket er dets evne til at forsætte sig i forhold til andre væsner. Mennesket kan forstå dyret ved at afdække omgivelserne med henvisning til dyrets eget telos, hvorimod dyret er bundet til den fortolkningsramme, som dets instinkter allerede har fastsat. Selve mulighedsbetingelsen for denne forskel består i, at mennesket forstår det værende som værende frem for ren affekt, fordi dette sikrer, at mennesket forstår det værende som noget, der kan afdækkes på mange forskellige måder af andre livsvæsner.

For at opsummere kan vi sige, at Heidegger er ontologisk antropocentrisk, men epistemologisk ikke-antropocentrisk, såfremt at det ontologisk særegne ved mennesket er, at det er åbent over for andre væsner, som det forstår som forskellige handlingsbevægelser, der indgår i og modificerer den samme meningsfulde helhed, som det selv lever i. Formuleret i den spekulative realismes terminologi er menneskets korrelation allerede afhængigt af og responsivt over for andre korrelationer (hvad enten denne andethed er sociokulturel, historisk eller artsmæssig). ${ }^{9}$

7 Det er ikke dermed sagt, at vores samværen med dyrene er identisk med vores samværen med menneskene, for der er en grundlæggende forskel på, hvordan mennesker og dyr forholder sig til verden som et mulighedsrum. Det vender jeg tilbage til om lidt.

8 Se i denne forbindelse Heidegger (1983, 311ff; samt diskussionen af kinesis i 2002; 1976, 239_ 301).

9 På dette punkt ser vi også forskellen mellem Nagels og Heideggers tilgang til det andet livsvæsen. For Nagel forbliver den anden korrelation et mysterium, fordi vi i hans optik enten holder os til vort eget perspektiv eller hopper over i en objektiv beskrivelse, der netop forsøger at undgå ethvert perspektiv. Hvis vi derimod følger Heideggers hermeneutiske fænomenologi, udspringer en sådan opsplitning af en traditionel metafysisk forståelse af såvel subjek- 
$\mathrm{Nu}$ mangler vi den normative antropocentrisme. Som andre moralfilosofiske emner finder man kun forsvindende få eksplicitte bemærkninger herom i Heideggers værk, så på dette punkt kræver vor analyse en mere selvstændig rekonstruktion.

\section{Mod en frnomenologisk antropoexcentrisme}

Spørgsmålet om normativ antropocentrisme handler om, hvor meget moralsk værdi, vi skal tilskrive dyrenes liv. Fra et Heideggersk perspektiv er dette dog det forkerte spørgsmål at stille. Implicit i selve formuleringen ligger nemlig den antagelse, at vi frit kan vælge eller fravælge at tilskrive noget værdi. Spørgsmålet antager, at der på den ene side gives værdineutrale objekter (i dette tilfælde dyr), som efterfølgende via en distinkt proces skal tilskrives en moralsk status. Dermed er spørgsmålet fanget i en anden ontologisk spørgehorisont end fænomenologiens, idet spørgsmålet i sig selv opererer med en klar skelnen mellem fakta og værdi, mellem det rent deskriptive og det rent normative. Som Heidegger skriver andetsteds, giver det kun mening at tale om værditilskrivelse, hvis man allerede antager en sådan objektivisering af det værende og af verden, at al meningsfuldhed må tilskrives menneskets egen behandling af et meningsløst univers (Heidegger 1950, 101). ${ }^{10}$ For Heidegger er spørgsmålet om normativ antropocentrisme altså et karakteristisk moderne spørgsmål - og dermed også et antropologisk spørgsmål - der på den ene side lægger op til en forhåndenværende ontologi og på den anden side åbner op for en subjektivistisk og i sidste ende nihilistisk etik. ${ }^{11}$

Fra et fænomenologisk-ontologisk perspektiv må vi indvende mod spørgsmålet, at moralsk værdi ikke er noget, som vi aktivt tilskriver objekter. I stedet er livsvæsners 'værdi' allerede givet i vores oprindelige forståelse af dem - i vores afdækning af dyret som en bevægelse, der stræber mod sit eget telos. Dette betyder, at vi skal være påpasselige med at vurdere fænomenologien ud fra de samme kriterier som den moderne normative etik, idet ambitionen på ingen måde er at komme med klare handlingsforskrifter. Fænomenologiens opgave er og bliver at beskrive erfaringens grundlæggende strukturer, hvilket i etisk forstand vil sige at beskrive den erfaring, hvori vi føler os draget til at tage vare på et andet væsens liv.

På dette punkt viser Heideggers beskrivelse af vores triangulerende åbenhed over for dyret sig at være væsentlig, eftersom korrelationernes responsivitet, som beskrevet af fænomenologien, er en forudsætning for mange af de handlingsforskrifter, som man

tivitet som objektivitet. Hans pointe er derimod, at vi på det præ-reflektive niveau uundgåeligt forholder os til andre korrelationer eller perspektiver. Vi forstår med andre ord os selv, de andre væsner og vores omgivelser med udgangspunkt i én samlet fortolkningshelhed. Med denne triangulering som teoretisk fundament kan det fremmedpsykiske (hvad enten menneskeligt eller ikke-menneskeligt) på ingen måde blive et filosofisk mysterium - højst noget som vi pga. faktiske omstændigheder (endnu) ikke forstår særlig godt.

10 Se desuden Beinsteiner 2017.

11 I forhold til dette sidste punkt er han enig med fx MacIntyres (2007) diagnose af moderne moralfilosofi, og han ser, igen som MacIntyre, Nietzsche som kulminationen på det modernes opsplitning af væren og værdi. 
finder i den moderne normative dyreetik på trods af distancen mellem disse to filosofiske traditioner. For at tage et enkelt eksempel, så skriver Donaldson og Kymlicka i deres indflydelsesrige Zoopolis: 'Vores grundlæggende position er, således, at dyr har ukrænkelige rettigheder i kraft af deres sanselighed [sentience] og selv [selfhood], i kraft af det faktum, at de har subjektive erfaringer af verden'. Og lidt senere: 'Det, der betyder noget for sanselige væsner [sentient beings], betyder noget, fordi det betyder noget for dem' (Donaldson and Kymlicka 2013, 31, 33). ${ }^{12}$ Selve muligheden for en normativ teori om dyreetik og dyrerettigheder afhænger altså af et opgør med den epistemologiske antropocentrisme, fordi det kun giver mening at gå op i dyrevelfærd, hvis vi allerede har en form for adgang til dyrenes subjektive erfaring af verden og en idé om, hvad der betyder noget for dem.

Heideggers begreb om forsættelse som en præ-reflektiv triangulering, der åbner os over for andre væsners mulighedsstrukturer og telos, giver, om ikke andet, et stærkt teoretisk fundament for denne tanke. Fordelen ved den Heideggerske tilgang, der her er skitseret, er, at den undgår såvel den skepticisme eller tilbageholdenhed, der følger, hvis vi tager Nagels skelnen mellem det subjektive og det objektive for bogstaveligt, og de metodiske problemer, der følger, hvis vi tager posthumanismens og den spekulative realismes analogier og metaforer for alvorligt. Menneskets 'korrelation' må principielt være åben over for andre væsners 'korrelation' på en grundlæggende og førteoretisk måde, hvis det overhovedet skal give mening at påbyde mennesker, at de skal tage ansvar for disse fremmede væsner.

Så langt, så godt. Hvis fænomenologien, som jeg har argumenteret for, ikke er epistemologisk antropocentrisk, synes den at være kompatibel med - måske endda en forudsætning for - en normativ ikke-antropocentrisme. Spørgsmålet er nu om ontologisk antropocentrisme i sig selv fører til normativ antropocentrisme?

Heidegger afviser eksplicit, at hans skelnen mellem verdensbyggende, verdensfattig og verdensløs skulle udgøre en form for normativ rangering. ${ }^{13}$ Men ikke nok med det, så argumenterer Heidegger på sin vis imod, at der skulle være en nødvendig sammenhæng mellem hans ontologiske antropocentrisme eller exceptionalisme og andre mere problematiske former for antropocentrisme. Som Heidegger skriver i 1929 med henvisning til samtidens kritik af Væren og tid:

Og hvad angår (...) forbeholdet om et 'antropocentrisk standpunkt' i Væren og tid forbliver denne indvending, der nu alt for ivrigt er i omløb, intetsigende så længe man undlader at gennemtænke fremgangsmåden, at begribe ansatsen af og målet med problemudviklingen i Væren og tid, der netop gennem udarbejdelsen af Daseins transcendens bringer 'mennesket' i 'centrum' på en sådan måde, at dets intethed blandt helheden af det værende [Nichtigkeit im Ganzen des Seienden] allerførst kan og skal blive et problem. Hvori består faren ved et 'antropocentrisk standpunkt'. der netop gør sig alle anstrengelser for at vise, at Daseins væsen - dét, som er sat i 'centrum' - er ekstatisk, dvs. 'excentrisk'?

12 Denne henvisning skylder jeg Sikka $(2017,86)$.

13 'Sammenligningen mellem dyr og menneske, karakteriseret ved verdensfattighed og verdensbyggelse, udgør i hvert fald ingen bedømmelse og vurdering i forhold til fuldkommenhed og ufuldkommenhed - ganske uagtet, at en sådan bedømmelse er faktisk overilet og upassende' (Heidegger 2002, 286). 
På den ene side må vi medgive, at positionen i Væren og tid er antropocentrisk, for den tager netop udgangspunkt i en analyse af mennesket som Dasein; men på den anden side understreger Heidegger - $\mathrm{i}$ forlængelse af hans kritik af filosofisk antropologi til fordel for fænomenologisk ontologi - at undersøgelsen har til formål at vise, hvordan Daseins væsen udgøres af en værensforståelse, der åbner det udadtil, også over for andre væsner. Daseins væsen er med andre ord ekstatisk eller excentrisk: Det er det metodiske og ontologiske udgangspunkt for fænomenologien; men samtidig er det i sig selv 'intet' - et 'intet' der åbner op for en analyse af det værende som helhed, og som derfor bestandigt orienterer sig væk fra det blot menneskelige centrum i sin åbenhed over for andre (også ikke-menneskelige) fænomener. ${ }^{15}$ Daseinsanalytikken er altså en ontologisk antropocentrisme, fordi den postulerer en ontologisk forskel på menneske og dyr, men samtidig er den en antropoexcentrisme, fordi Dasein har en værensforståelse, der åbner det op over for andre værensregioner end det blot menneskelige.

Den samme pointe kan formuleres med terminologien fra Die Grundbegriffe der Metaphysik: Kun et verdensbyggende væsen, der ikke er bundet af sin disinhibitionsring, kan gå op i, hvordan det er at være et andet væsen. Dermed er det også kun et verdensbyggende væsen, der kan bekymre sig om og drage omsorg for et andet (evt. verdensfattigt) væsen. Forudsætningen for en ikke-antropocentrisk etik er dermed, at der gives i hvert fald ét væsen, der ontologisk udmærker sig ved, at det kan forholde til sig det værende som værende, og ved, at dets verdensforhold er konstitueret ved en temporalitet og modalitet, der ikke er fastsat af de blotte instinkters teleologi. Hvis dette er sandt, river posthumanismens og den spekulative realismes udslettelse af den antropologiske differens til fordel for en flad ontologi tæppet væk under den (zoecentriske) etik, som de ellers stræber imod, for uden et begreb om ontologisk exceptionalisme har de ingen ontologi for det væsen, der kan tage ansvar for andre væsner.

Den Heidegger-inspirerede antropoexcentrisme, som jeg forsvarer her, minder i dens topologiske struktur og i dens kritik af posthumanismen om Peter Kemps 'antropocentrifugale' etik. Også Kemp insisterer på, at kun væsner, der opfylder visse ontologiske forudsætninger, meningsfuldt kan tilskrives ansvar. Ifølge Kemp har mennesker således en 'erfaring af virkelig tid'. der giver dem muligheden for 'at kunne danne sig en narrativ vision af det gode liv' og dermed også muligheden for at kunne tage ansvar for noget (Kemp 1994, 186, fodnote). Det følger heraf, at enhver dyre- eller bioetik må begrundes i den antropologiske differens. Som Kemp skriver, 'er det snarere

Som vi så i afsnit 1.1, kunne Heidegger meget vel have bl.a. Husserls indvendinger mod $V \mathfrak{x}$ ren og tids subjektivisme og antropocentrisme i tankerne.

15 Som Thomas Schwarz Wentzer forklarer termen: 'Excentricitet skal forstås ikke som en psykologisk egenskab, men som et ontologisk kendetegn. Termen betyder, bogstaveligt, at vi finder os selv decentrerede eller 'uden for vores centrum'. Faktisk er der intet sådant centrum som kunne demarkere den oprindelse eller den jeg-pol, fra hvilken vi selv påbegynder vores verdenslige engagement. Excentricitet dekonstruerer ethvert forsøg på at tænke den menneskelige natur som en essens inden i os. Det er et spatialt og topologisk begreb, der adresserer, hvordan det er at være én selv ved at være overladt til verden' (Wentzer 2017, 356). 
forskellen end ligheden mellem menneske og dyr, der forpligter mennesket overfor dyrene' (s. 186, fodnote).

På trods af denne lighed ville Heidegger dog mene, at Kemp forbliver inden for en traditionel metafysisk horisont, når han beskriver menneskets forpligtelse over for dyrene som en udvidelse af den 'menneskelige persons ukrænkelighed' med den dertilhørende moralske respekt (s. 185). Selve personbegrebet beror, som vi så Heidegger indvende over for Husserl og Scheler, på en problematisk græsk-kristen filosofisk antropologi, der i sidste ende truer med at underminere Kemps bioetik, idet den bygger på forståelsen af mennesket som animal rationale. Set fra dette udgangspunkt har vi blot to valgmuligheder: Enten mangler dyret den afgørende moralske faktor (som er en form for animal sine rationale), eller også adskiller dyret sig ikke væsentligt fra mennesket. På trods af sin fremhævelse af den antropologiske differens synes Kemp at vælge den sidste mulighed, når han insisterer på at kalde alle livsvæsner (inklusiv naturen som helhed (s. 186)) for 'personer'. Når han således igen opbløder forskellen på menneske og dyr, ender han med at underminere det ontologiske udgangspunkt for den antropocentrifugale etik. Fra et fænomenologisk perspektiv må vi derimod insistere på, at det også i etikken handler om at lade fænomenerne fremtræde inden for deres egen fremtrædelseshorisont, og her synes mennesket at fordre en anden type af afdækning end dyrene, idet mennesket må antages at forholde sig anderledes til sine muligheder, end for eksempel billen gør det.

Denne pointe kompliceres, men modsiges ikke, af det faktum, at fremtrædelseshorisonter er historisk variable, som Heidegger også medgiver. Forskellige folkeslag i forskellige perioder afdækker ting forskelligt, og dermed har de også forskellige forståelser af, hvordan man forholder sig ansvarligt til disse ting. Den tidlige Heideggers foretrukne eksempel på dette er animisme. Han bekræfter, at i 'myten' og i 'kunsten' erfarer man visse ting, der fra et videnskabeligt perspektiv er 'døde', som 'besjælede' (Heidegger 1983, s. 299f). Hvordan man forholder sig 'ansvarligt' til totemmet afhænger, i forlængelse af min analyse, af hvilken type af besjæling der er på spil. Dette må i sidste ende afgøres fænomenologisk. Erfares dette totem som verdensbyggende eller verdensfattigt? Står dets telos til forhandling eller er det forudbestemt?

Den afgørende pointe er, at etikken bliver nødt til at tage udgangspunkt i menneskets dynamiske og verdensbyggende forhold til sine egne muligheder, da dette forhold gør moralsk stillingtagen, begrundelse og diskussion mulig. Det er i vores fremtrædelseshorisont, at forskellen på menneske, dyr, totem og objekt træder frem som en etisk relevant forskel. Hvis mennesket var indfanget i en disinhibitionsring og dermed låst fast til sit telos, ville end ikke fordringen om at tage ansvar for et fremmed væsen melde sig. Når Kemp udvider personbegrebet til også at omfatte dyrene og naturen, mister han blikket for den grundlæggende etiske erfaring af mennesket som et væsen, der forholder sig dynamisk til sin verden. På dette punkt er Heideggers excentrisme bedre stillet, idet den inviterer os til at forstå det verdensbyggende menneske som adskilt fra dyrene og dog forbundet med dyrene, idet den verden, vi deler med dem, udgøres af komplekse, asymmetriske og dog gensidigt responsive mulighedsstrukturer. 
På trods af dette forsvar for en Heidegger-inspireret antropoexcentrisme må vi medgive, at Heideggers tilgang til spørgsmålet om dyrene på bestemte punkter er ganske mangelfuld. Hvilke argumenter og hvilken evidens har han givet for sin påstand om, at det er mennesket og kun mennesket, der er verdensbyggende, og at alle ikkemenneskelige dyr uden undtagelse er verdensfattige? Han bygger på sin samtids biologi, og dog forbliver hans pointe en rent begrebslig pointe. I min rekonstruktion kan vi omsætte hans tese om at mennesket er verdensbyggende, til tesen, at der er en ontologisk forskel på Dasein og ikke-Daseinsmæssige livsvæsner, men at dette hverken fører til epistemologisk eller normativ antropocentrisme. At dette er en ren begrebslig pointe betyder, at den antropologiske differens er tentativ. Den ontologiske exceptionalisme vedrørende Dasein svarer ikke nødvendigvis fuldstændig overens med arten homo sapiens. Omfanget af et sådant overlap må afgøres empirisk og ikke begrebsligt. Det kan være, at fremtidige empiriske undersøgelse lægger op til den tolkning, at visse andre dyrearter har en værensforståelse, der minder om menneskenes i den forstand, at de forstår det værende som værende, og at de derfor kan forsætte sig i forhold til andre væsners disinhibitionsringe og forstå 'hvad, der betyder noget for dem'. Det er logisk muligt, at der findes dyr, der går op i deres egen væren på samme måde som mennesket, og vi må også medgive, at der findes mennesker, som ikke gør. Komatøse patienter og hjernedøde udgør sådanne fænomenologiske tvivlstilfælde. Er de responsive? Er de verdensbyggende? Går de op i deres egen væren?

Tilsvarende kunne man forestille sig, at der på et senere tidspunkt gives andre fænomenologiske tvivlstilfælde, hvor vi præ-reflektivt forstår et ikke-menneskeligt væsen (lad os sige en kunstig intelligens eller en avanceret primat) som værende i stand til at overskride sine instinkter og dermed forholde sig dynamisk til sit eget telos. Vi ville i så fald forholde os anderledes til et sådant væsen - også i etisk forstand - end vi gør til væsner, der er verdensfattige eller verdensløse, fordi vi i sådanne tilfælde præreflektivt vil forvente en dynamisk gensidighed i verdens- og værensforståelsen, som ikke er tilstede, når vi 'går-med' et 'dyr' (i traditionel forstand). Dette betyder imidlertid ikke, at distinktionen mellem verdensbyggende, verdensfattig og verdensløs involverer en normativ rangering. Vi forholder os blot anderledes - igen også i etisk forstand - til disse væsner. Vi kan drage omsorg for billen, indfanget i sine instinkters magiske ring, fordi vi allerede forstår den som stræbende efter dens eget bestemte telos - også selvom vi ikke forventer af billen, at den drager den samme omsorg for os.

\section{Konklusion}

Jeg har i denne artikel diskuteret, hvorvidt fænomenologien er antropocentrisk, og jeg er nu nået frem til svaret: både og. Dette svar skyldes ikke vægelsind, men en række komplikationer i forhold til både det fænomenologiske projekt og i forhold til selve begrebet 'antropocentrisme'.

Det fænomenologiske projekt er antropocentrisk i den forstand, at det tager udgangspunkt $i$ en analyse af menneskets forhold til verden. Fænomenologien distance- 
rer sig dog fra antropologien ved at mene, at den rette analyse af dette forhold overskrider en blot analyse af menneskets væren og tillader os at stille spørgsmålet om verdenskonstitution eller spørgsmålet om væren som sådan.

Undersøgelsen har desuden vist, at begrebet 'antropocentrisme' i sig selv er tvetydigt, og at det er nødvendigt at skelne mellem ontologisk, epistemologisk og normativ antropocentrisme. Med denne skelnen for øje har jeg argumenteret for, at Heideggers fænomenologiske ontologi tentativt insisterer på, at der er en ontologisk forskel på menneske og dyr, men at denne forskel hverken implicerer epistemologisk eller normativ antropocentrisme. I Heideggers fænomenologi er Dasein - det verdensbyggende væsen - det ontologiske centrum; men den ring, der omgiver dette væsen, kendetegner sig netop ved, at den epistemologisk og etisk set åbner sig udadtil. At mennesket er verdensbyggende, betyder, at vi præ-reflektivt forsætter os i forhold til andre korrelationer. Vi triangulerer konstant vores forståelse af vores omgivelser, andre livsvæsner og os selv i forhold til hinanden. En sådan triangulering er, ex hypothesi, kendetegnende for menneskets væren; men samtidig er det netop denne triangulering, der gør os i stand til at forstå og drage omsorg for andre væsner. Således bliver den ontologiske antropocentrisme i fænomenologien til en epistemologisk og etisk ikkeantropocentrisme. Jeg har til slut foreslået, at vi kalder denne særlige komplikation af de forskellige former for antropocentrisme og ikke-antropocentrisme for en fænomenologisk antropoexcentrisme.

\section{LITTERATUR}

Agamben, Giorgio

2004 The Open: Man and Animal, oversat af Kevin Attell, Stanford University Press.

Beinsteiner, Andreas

2017 'The 'As' and the Open: On the Methodological Relevance of Heidegger's Anthropocentrism", Studia Phaenomenologica 17, 41-56.

https://doi.org/10.5840/studphaen2017173.

Bogost, Ian

2012 Alien Phenomenology, or What It's Like to Be a Thing, University of Minnesota Press.

Braidotti, Rosi

2013 The Posthuman, Polity Press.

2019 "A Theoretical Framework for the Critical Posthumanities", Theory, Culture $\mathcal{E}$ Society 36 (6), 31-61. https://doi.org/10.1177/0263276418771486.

Ciocan, Cristian.

2019 "Embodiment and Animality", Journal of the British Society for Phenomenology 50 (2), 87-103. https://doi.org/10.1080/00071773.2018.1517505.

Davidson, Donald

1982 “Rational Animals", Dialectica 36 (4), 317-27. 
Derrida, Jacques

1972 Marges de la philosophie, Les Éditions de Minuit.

Donaldson, Sue \& Will Kymlicka

2013 Zoopolis: A Political Theory of Animal Rights, Oxford University Press.

Ferrando, Francesca

2016 "The Party of the Anthropocene: Post-Humanism, Environmentalism and the Post-Anthropocentric Paradigm Shift", Relations: Beyond Anthropocentrism 4 (2), 159-73. https://doi.org/10.7358/rela-2016-002-ferr.

Foster, Charles

2018 Mit Liv Som Dyr, Gyldendal.

Foucault, Michel

2006 Ordene og tingene: En arkæologi om humanvidenskaberne, oversat af Mogens Chrom Jacobsen, Det Lille Forlag

Heidegger, Martin

1950 Holzwege, Vittorio Klostermann.

1975 Prolegomena zur Geschichte des Zeitbegriffs, Vittorio Klostermann.

1976 Wegmarken, Vittorio Klostermann.

1983 Die Grundbegriffe der Metaphysik: Welt, Endlichkeit, Einsamkeit, Vittorio Klostermann.

2002 Grundbegriffe der aristotelischen Philosophie, Vittorio Klostermann.

2007 Væren og tid, oversat af Christian Rud Skovgaard, Klim.

Husserl, Edmund

1987 Aufsätze und Vorträge, Martinus Nijhoff.

1991 Ideen zu einer reinen Phänomenologie und phänomenologischen Philosophie. Zweites Buch: Phänomenologische Untersuchungen zur Konstitution, Kluwer.

Kemp, Peter

1994 Det uerstattelige: En teknologi-etik, Spektrum.

MacIntyre, Alasdair

2007 After Virtue: A Study in Moral Theory, University of Notre Dame Press.

Meillassoux, Quentin

2014 After Finitude: An Essay on the Necessity of Contingency, Bloomsbury.

Merleau-Ponty, Maurice

1945 Phénoménologie de la perception, Gallimard.

Morton, Timothy

2017 Humankind: Solidarity with Nonhuman People, Verso.

Nagel, Thomas

1974 "What Is It Like to Be a Bat?", Philosophical Review 83, 435-50. https://doi.org/10.2307/2183914.

Sartre, Jean-Paul

2013 Væren og intet: Et essay om fænomenologisk ontologi, oversat af Mogens Chrom Jacobsen, Philosophia.

Sikka, Sonia

2017 Heidegger, Morality and Politics: Questioning the Shepherd of Being, Cambridge 
University Press.

Wentzer, Thomas Schwarz

2017 "Rethinking Transcendence: Heidegger, Plessner and the Problem of Anthropology", International Journal of Philosophical Studies 25 (3), 348-362. https://doi.org/10.1080/09672559.2017.1320017.

Nicolai Krejberg Knudsen, ph.d. Linacre College, University of Oxford 